\title{
PENGEMBANGAN MEDIA PEMBELAJARAN KAMUS IPA FISIKA BERGAMBAR UNTUK MENINGKATKAN MINAT BELAJAR SISWA MTS NW SENYIUR KELAS VIII PADA MATERI ALAT OPTIK TAHUN AJARAN 2018/2019
}

\author{
Habib Tantawi ${ }^{1}$, Johri Sabaryati ${ }^{1}$, N.W.S. Darmayanti ${ }^{1}{ }^{1}$ \\ 1)Program Studi Pendidikan Fisika Universitas Muhammadiyah Mataram, Mataram, NTB, Indonesia \\ Corresponding author : N.W.S Darmayanti \\ E-mail : wyndarmayanti@gmail.com
}

\section{Diterima 01 November 2019, Disetujui 19 November 2019}

\begin{abstract}
ABSTRAK
Tujuan dari penelitian ini untuk mengembangkan media pembelajaran Kamus IPA Fisika Bergambar pada pokok bahasan Optik untuk meningkatkan minat belajar siswa. Penelitian ini menggunakan metode research and development $(R \& D)$. Sebagai subjek dalam penelitian ini adalah siswa MTs NW Senyiur kelas VIII. Model pengembangan yang digunakan adalah Borg and Gall yang terdiri dari10 langkah yang harus diikuti untuk menghasilkan produk berupa Kamus IPA Fisika Bergambar. Data diperoleh melalui wawancara, angket dan dokumentasi. Teknik analisis data yang digunakan adalah deskriptif kualitatif untuk mengukur minat belajar siswa. Hasil penelitian menunjukkan bahwa media pembelajaran yang dikembangkan berupa Kamus IPA Fisika Bergambar memiliki kriteria yang sangat baik berdasarkan penilaian dari ahli dan praktisi. Media pembelajaran Kamus IPA Fisika Bergambar yang dikembangkan juga memiliki kriteria yang sangat baik untuk meningkatkan minat belajar siswa dengan persentase sebesar $70 \%$ bila dibandingkan sebelum menggunakan Kamus IPA Fisika Bergambar yaitu sebesar $47 \%$. Peningkatan minat belajar secara klasikal juga berada pada kriteria sedang dengan normalisasi gain sebesar 0,44 . Berdasarkan hasil dari penelitian ini dapat disimpulkan bahwa media pembelajaran Kamus IPA Fisika Bergambar dapat meningkatkan minat belajar siswa kelas VIII di MTs NW Senyiur Tahun Pelajaran 2018/2019.
\end{abstract}

Kata Kunci: Pengembangan Kamus IPA Fisika, Bergambar, Minat Belajar

\begin{abstract}
The study aims to develop learning media on the Picture Physics Science on the subject of optics, to increase students' interest in learning. This study uses the research and development (R \& D) method. As the subjects in this study were MTs NW Senyiur class VIII students. The development model used is Borg and Gall which consists of 10 steps that must be followed to produce a product in the form of Picture Physics Science Dictionary. Data obtained through interviews, questionnaires and documentation. The data analysis technique used is descriptive qualitative to measure student learning interest. The results showed that learning media developed in the form of Picture Physics Science Dictionary had very good criteria based on the judgment of experts and practitioners. Learning media The Pictorial Physics Science Dictionary developed also has very good criteria for increasing student learning interest by a percentage of $70 \%$ compared to before using the Picture Physics Science Dictionary which is equal to $47 \%$. Increased interest in classical learning is also in the medium criteria with normalization gain of 0.44 . Based on the results of this study, it can be concluded that the learning media of Picture Physics Science Dictionary can increase the learning interest of Grade VIII students in NW MTs Senyiur 2018/2019 Academic Year.
\end{abstract}

Keywords: Development of Science Physics Dictionary, Drawing, Interest in Learning

\section{PENDAHULUAN}

Pada hakikatnya IPA dibangun atas dasar produk ilmiah, proses ilmiah, dan sikap ilmiah. Selain itu, IPA dipandang pula sebagai proses, sebagai produk, dan secara prosedur. Secara umum IPA meliputi tiga bidang ilmu dasar, yaitu biologi, fisika, dan kimia. Fisika merupakan salah satu cabang dari IPA. Hakikat Fisika adalah ilmu pengetahuan yang mempelajari tentang gejala-gejala alam melalui serangkaian proses yang dikenal dengan proses ilmiah yang dibangun atas dasar sikap ilmiah dan hasilnya terwujud sebagai produk ilmiah yang tersusun atas tiga komponen terpenting berupa konsep, prinsip, dan teori yang berlaku secara universal (Trianto, 2014). 
Pada proses pembelajaran siswa hanya mengetahui konsep atau persamaan matematisnya, namun kebingungan saat ditanya mengenai makna fisis atau definisi dari istilah fisika. Sesuai dengan penelitian di MTs NW Senyiur sebagian besar siswa hanya mengandalkan LKS sebagai sumber belajar. Seperti yang diketahui, isi dari LKS Madrasah Tsanawiah (MTs) NW Senyiur merupakan ringkasan-ringkasan materi, sehingga penjabaran makna dari istilah-istilah fisika yang ada masih sangat terbatas. Hal ini merupakan salah satu permasalahan dalam proses pembelajaran dan akan menyebabkan tujuan pembelajaran yang diharapkan sulit untuk dicapai. Untuk mengatasi masalah tersebut diperlukan adanya sumber belajar yang memuat istilah-istilah fisika.

Sumber belajar merupakan segala sesuatu yang meliputi data, orang atau benda. Adanya sumber belajar tersebut diharapkan siswa akan lebih mudah dalam memahami materi yang disampaikan oleh guru khususnya dalam mata pelajaran fisika. Salah satu sumber belajar yang memuat istilah-istilah fisika adalah kamus fisika. Akan tetapi kamus fisika yang beredar dipasaran kurang membantu siswa dalam belajar maupun memahami konsep fisika. Siswa cenderung lebih bisa memahami konsep jika berkaitan dengan lingkungan di sekitarnya. Oleh karena itu perlu dikembangkan kamus fisika yang bisa memberikan pemahaman konsep yang lebih baik untuk siswa. Adapun kamus fisika tersebut ialah kamus fisika bergambar, yang dimana selain menjelaskan tentang definisi dari istilah fisika, kamus ini juga menyertakan gambar yang terkait dengan istilah tersebut.

Buku kamus IPA Fisika bergambar merupakan buku acuan yang memuat kata, gambar dan penjelasan, disertai rumusnya, kamus biasanya disusun menurut abjad berikut keterangan tentang makna, pemakaian atau terjemahannya (Anonim, 2018). Buku kamus IPA fisika bergambar merupakan penjabaran dan definisi singkat tentang fisika agar mudah dipahami, dan memiliki ukuran yang praktis agar mudah dibawa kemana-mana. Adapun manfaat dari kamus IPA fisika bergambar memudahkan dalam pembelajaran, dan memudahkan mencari pengertian-pengertian dari materi yang diinginkan mengikuti huruf awal seperti kamus yang ada.

Berdasarkan paparan permasalahan diatas peneliti ingin melakukan penelitian dengan judul "Pengembangan Media Pembelajaran Kamus IPA Fisika Bergambar Untuk Meningkatkan Minat Belajar Siswa MTs NW Senyiur pada Materi Alat Optik
Kelas VIII" dengan harapan dapat meningkatkan minat belajar siswa.

\section{Metode Pengembangan \\ Metode Penelitian}

Jenis Penelitian ini adalah penelitian pengembangan (Reseach \& Development). Reseach \& Development adalah metode penelitian yang digunakan untuk menghasilkan produk. Model pengembangan ini ialah model Borg and Gall yaitu penelitian yang menghasilkan atau mengembangkan produk tertentu, dan menguji keefektifan produk tersebut (Sugiyono, 2017). Produk yang dihasilkan dalam penelitian pengembangan ini adalah Kamus IPA Fisika Bergambar.

Desain penelitian ini menggunakan satu kelas sampel sebagai kelas uji coba (One Group Pre- Test and Post-test Design). Teknik pengumpulan data pada penelitian ini adalah angket dan dokumentasi. Angket digunakan untuk mengumpulkan data tentang kelayakan, keefektifan, dan keefisienan media pembelajaran yang dibuat dan akan dijawab oleh responden yang terkait pembelajaran antara lain: ahi materi, ahli media dan siswa sebagai pengguna media pembelajaran kamus fisika bergambar.

\section{Lokasi dan Waktu penelitian}

Penelitian ini telah dilaksanakan di Madrasah Tsanawiyah (MTs) Senyiur sederajat pada bulan Agustus- September tahun ajaran 2018/2019 pada siswa MTs kelas VIII.

\section{Langkah-Langkah Penelitian}

Langkah-langkah penelitian dan pengembangan Kamus IPA Fisika Bergambar sebagai berikut:

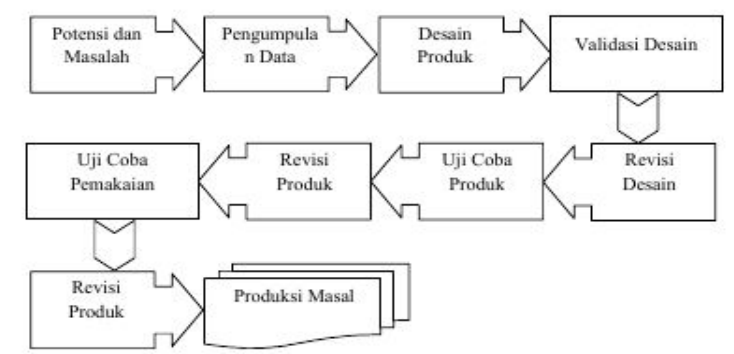

Pengembangan R \& D

Penelitian ini dilakukan sampai pada tahap uji coba produk karena keterbatasan waktu dan dana. Media dikatakan valid apabila telah divalidasi oleh ahli dan diuji kefektifannya serta keefisiennya oleh peneliti dengan adanya peningkatan minat belajar pada diri masing-masing siswa. 


\section{Metode penelitian Tahap I \\ Potensi Dan Masalah}

Penelitian dapat berangkat dari potensi dan masalah yang ada. Potensi adalah segala sesuatu yang bila didaya gunakan akan memiliki nilai tambah (Sugiyono,2017). Potensi yang ditemukan dalam penelitian ini adalah kamus IPA fisika bergambar dalam kegiatan pembelajaran. Masalah dalam penelitian ini adalah kurangnya minat belajar siswa kelas SMP/MTs kelas VIII terhadap mata pelajaran Fisika.

\section{Pengumpulan Data \\ Langkah yang diambil setelah} ditemukan potensi dan masalah dalam penelitian ini adalah mengumpulkan informasi. Informasi dapat dilakukan sebagai bahan untuk perencanaan produk tertentu. Pada penelitian ini, peneliti akan menghasilkan dan mengembangkan produk berupa kamus IPA fisika bergambar. Berdasarkan hasil pengumpulan informasi yang telah dilakukan disekolah, ditemukan permasalahan yaitu rendahnya minat belajar pada siswa. Pemicu salah satunya adalah kurangnya media pembelajaran yaitu buku pegangan siswa. Oleh karena itu, peneliti akan mengembangkan media pembelajaran seperti kamus IPA fisika bergambar yang menarik dan sangat praktis di gunakan dalam pembelajaran.

\section{Desain Produk}

Pengembangan media pembelajaran kamus IPA fisika bergambar dilakukan dengan uji coba produk pengembangan menggunakan desain validasi logis dengan tipe validasi isi (content validity). Validasi ini dilakukan para ahli bidang studi. Ahli pengukuran dan para ahli yang memiliki keahlian yang relevan dengan bidang kajiannya (setyosari, 2013).

Pada tahap ini yang dilakukan adalah mendesain kamus fisika bergambar untuk sebagai sumber belajar siswa. Peneliti mendesain kamus fisika bergambar ini dengan menggunakan Microsoft Word, Microsoft Publisher, Adobe Photoshop 7 dan Corel Draw X6. Setelah proses desain kamus selesai, selanjutnya kamus dikonsultasikan kepada dosen pembimbing untuk di telaah agar mendapat saran perbaikan hingga kamus yang dihasilkan dinyatakan siap oleh dosen pembimbing untuk divalidasi.

\section{Validasi Desain Produk}

Validasi produk dapat dilakukan dengan cara menghadirkan beberapa pakar tenaga ahli yang sudah berpengalaman untuk menilai produk baru yang dirancang tersebut
(Sugiyono, 2017). Validasi isi dilakukan oleh para ahli bidang studi, ahli pengukuran, dan pakar yang memiliki keahlian yang relevan dengan bidang kajiannya.

\section{Perbaikan Desain Produk}

Semua kelengkapan dan peralatan media pembelajaran IPA Fisika bergambar didesain semenarik mungkin agar dapat meningkatkan minat dan perhatian siswa dalam proses pembelajaran.

\section{Uji Coba Produk}

Uji coba produk dilakukan pada siswa kelas VIII dan guru untuk dimintai tanggapan dan saran mengenai media pembelajaran kamus IPA Fisika bergambar.

\section{Jenis Data}

Jenis data dalam penelitian ini adalah data kualitatif dan data kuantitaif. Data kualitatif berupa komentar dari ahli materi, ahli media, praktisi lapangan, dan siswa terhadap media pembelajaran kamus IPA Fisika bergambar. Sedangkan data kuantitatif didapatkan dari skor validasi dari ahli materi, ahli media, praktisi lapangan, dan siswa, dikonversi skor tersebut.

\section{Instrumen Pengumpulan Data}

Instrumen penelitian digunakan untuk mengukur nilai variabel yang akan diteliti (Sugiyono, 2017). Secara spesifikasi fenomena yang terjadi disebut variable penelitian. Instrumen yang digunakan dalam penelitian ini lembar angket minat (kuisioner). Kuisioner merupakan teknik pengumpulan data yang dilakukan dengan cara memberi seperangkat pertanyaan atau pernyataan tertulis kepada responden untuk menjawabnya (Sugiyono, 2013).

Berbagai skala sikap dapat dikumpulkan melalui angket.Pada penelitian ini skala sikap yang digunakan adalah skala likert. Jawaban dari setiap item instrument yang menggunakan skala likert mempunyai garaduasi dari sangat positif sampai sangat negatif. (Uno, 2016)

Skala pengukuran yang digunakan untuk mengukur validasi produk dan minat belajar siswa adalah skala likert yang memiliki gradulasi penilaian dari sangat positif sampai sangat negatif. Teknik skorsing dalam skala likert adalah sebagai berikut:
1. Sangat Setuju (Sangat Positif)
diberi skor 5
2. Setuju (Positif) diberi skor 4
3. Kurang Setuju (Negatif) diberi skor 3 
4. Tidak Setuju (Sangat Negatif) diberi skor 2

5. Sangat Tidak Setuju (Sangat Negatif) diberi skor 1

\section{Teknis analisis data}

Analisis data dilakukan setelah proses pengumpulan data, dimana penelitian ini lebih menitik beratakan pada pengembangan media pembelajaran kamus IPA Fisika Bergambar. Angket yang digunakan harus dilakukan uji validasi dan uji releabilitas. Dimana teknik analisis data untuk percobaan ini adalah teknik angket dan wawancara. Angket diberikan kepada guru fisika dan siswa mengenai produk atau media yang akan dikembangkan. Dimana angket digunakan untuk menguji kelayakan media, sedangkan metode wawancara dilakukan pada beberapa tahap pengembangan yaitu analisis kebutuhan untuk pengembangan produk.

\section{Metode Penelitian Tahap II}

Model Rancangan Eksprimen Untuk Menguji

Uji coba produk merupakan bagian penting dalam penelitian pengembangan yang dilakukan setelah rancangan produk selesai.Uji coba produk dalam penelitian ini dilakukan untuk mengetahui apakah media pembelajaran kamus IPA fisika bergambar yang dikembangkan dapat meningkatkan minat belajar siswa belajar pada siswa atau tidak dapat meningkatkan minat belajar pada siswa.

Desain uji coba dilakukan dalam penelitian ini adalah dengan cara menerapkan media pembelajaran kamus IPA fisika bergambar dengan pengujian yang dilakukan dengan cara eksprimen yaitu untuk mengetahui peningkatkan minat belajar pada siswa dengan menggunakan media pembelajaran kamus IPA fisika bergambar. Desain penelitian yang digunakan adalah:

$\mathrm{O}_{1} \mathrm{XO}_{2}$
Gambar. 1 Desain Penelitian (Pretest-Postest
design)

Keterangan :

$0_{1}=$ minat sebelum menerapkan media pembelajaran kamus IPA fisika bergambar

$\mathrm{O}_{2}=$ minat setelah menerapkan media pembelajaran kamus IPA fisika bergambar

\section{Subjek Uji Coba}

Adapun subjek uji coba telah diteliti pada penelitian ini adalah peserta didik kelas VIII-8 Tahun 2018. Adapun obyek penelitian ini adalah peserta didik kelas VIII-b tahun 2018.
Teknik Pengumpulan Data

Teknik pengumpulan data minat belajar siswa adalah menggunakan angket minat belajar yang diberikan sebelum menggunakan media pembelajaran kamus IPA fisika bergambar dan setelah menggunakan media pembelajaran kamus IPA fisika bergambar. Angket minat terdiri dari pernyataan positif dan pernyataan negatif. (Uno, 2016)

\section{Teknik Analisis Data}

Teknik Analisis Data Angket Validasi Produk

Teknis analisis data pada penelitian ini bertujuan untuk mendapatlan perangkat pembelajaran yang berkualitas. Adapun langkah-langkah yang digunakan dalam memenuhi kriteria kualitas produk yang dikembangkan adalah sebagai berikut:

1. Data berupa skor ahli/praktisi yang diperoleh melalui lembar validasi yang dijumlahkan

2. Total skor actual yang diperoleh kemudian dikonvrsikan menjadi data kualitatif skala lima seperti pada tabel berikut:

Tabel 1. Konversi Data Kuantitatif ke Kualitatif Dengan Skala Lima

\begin{tabular}{|c|c|c|}
\hline Interval & Kriteria & Skor \\
\hline$(\mathrm{M}+1,50 \mathrm{~s})<\mathrm{X}$ & $\begin{array}{c}\text { Sangat } \\
\text { baik }\end{array}$ & $\mathrm{A}$ \\
\hline $\begin{array}{c}(\mathrm{M}+0,50 \mathrm{~s})<\mathrm{X} \leq(\mathrm{M} \\
+1,50 \mathrm{~s})\end{array}$ & Baik & $\mathrm{B}$ \\
\hline $\begin{array}{c}(\mathrm{M}-0,50 \mathrm{~s})<\mathrm{X} \leq(\mathrm{M} \\
+0,50 \mathrm{~s})\end{array}$ & $\begin{array}{c}\text { Cukup } \\
\text { baik }\end{array}$ & $\mathrm{C}$ \\
\hline $\begin{array}{c}(\mathrm{M}-1,50 \mathrm{~s})<\mathrm{X} \leq(\mathrm{M} \\
-0,50 \mathrm{~s})\end{array}$ & $\begin{array}{c}\text { Kurang } \\
\text { baik }\end{array}$ & $\mathrm{D}$ \\
\hline $\mathrm{X} \leq(\mathrm{M}-1,50 \mathrm{~s})$ & $\begin{array}{c}\text { Tidak } \\
\text { baik }\end{array}$ & $\mathrm{E}$ \\
\hline
\end{tabular}

Keterangan:

(Azwar, 2015)

$X=$ Total skor responden

$M=$ Mean ideal, $1 / 2$ (skor maksimal ideal+skor minimal ideal)

$\mathrm{s}=$ Simpangan baku ideal, $1 / 6$ (skor maksimal ideal-skor minimal ideal)

skor maksimal ideal $=\sum$ butir kriteria $\mathrm{x}$ skor tinggi

skor minimal ideal $=\sum$ butir kriteria $\mathrm{x}$ skor terendah

Berdasarkan kriteria yang terdapat pada tabel 1 kemudian dibuat kriteria validitas perangkat pembelajaran yang dikembangkan. Komponen perangkat pembelajaran yang dikembangkan memiliki jumlah butir pada lembar validasi untuk angket penilaian berbeda-beda, maka kriteria kevalidannya juga berbeda. Hasil validasi oleh ahli kemudian dikonversikan menjadi skala lima. Perangkat pembelajaran yang dikembangkan dikatakan 
valid, jika minimal tingkat validitas yang dicapai kategori baik.

\section{Teknik Analisis Data Angket Minat}

Analisis data dilakukan setelah proses pengumpulan data, dimana penelitian ini lebih menitik beratkan pada pengembangan kamus IPA fisika bergambar untuk meningkatkan minat belajar siswa kelas VIII. Angket yang digunakan harus dilakukan uji validasi dan uji reliabilitas. Dimana teknik analisis data untuk percobaan ini adalah tekhnik angket dan dokumentasi.

\section{Uji Validitas}

Untuk menghitung banyaknya pernyataan yang valid atau tidaknya dapat dihitung nilai validitas dengan rumus Pearson Product Moment adalah:

$r_{x y}=\frac{n \sum X_{i} Y_{i}-\left(\sum X_{i}\right) \cdot\left(\sum Y_{i}\right)}{\sqrt{\left\{n \sum X_{i}^{2}-\left(\sum X_{i}\right)^{2}\right\} \cdot\left\{n \cdot \sum Y_{i}^{2}-\left(\sum Y_{i}\right)^{2}\right\}}}$

Keterangan:

$r_{x y}=$ koefisien korelasi product moment

$\sum \mathrm{X}=$ jumlah skor butir soal

$\sum \mathrm{Y}=$ Jumlah skor total

$\mathrm{N}=$ Jumlah responden

$\sum \mathrm{X}^{2}=$ Jumlah kuadrat skor butir soal

$\sum \mathrm{Y}^{2}=$ Jumlah kuadrat skor total soal

$\sum X Y=$ Jumlah hasil kali skor butir soal

(Riduwan, 2014)

\section{Uji Realiabilitas}

Uji reliabilitas dilakukan untuk mengetahui reliabilitas angket, (instrumen) yang digunakan. Langkah-langkah mencari nilai reliabilitas sebagai berikut:

$$
r_{11}=\left(\frac{k}{k-1}\right)\left(1-\frac{\sum S_{i}}{S_{t}}\right)
$$

Keterangan:

$$
\begin{aligned}
& r_{11}=\text { Nilai reliabilitas } \\
& \sum S_{i}=\text { Jumlah varians skor tiap-tiap item } \\
& S_{t}=\text { Varians total } \\
& k=\text { Jumlah item }
\end{aligned}
$$

Selain itu perlu dicari nilai varians untuk menentukan reliabilitas angket minat belajar siswa menggunakan rumus sebagai berikut:

$$
S_{i}=\frac{\sum X_{i}^{2}-\frac{\left(\sum X_{i}\right)^{2}}{N}}{N}
$$

Keterangan:

$S_{i} \quad$ =Varians skor tiap-tiap item

$\sum X_{i}^{2} \quad=$ Jumlah kuadrat item $X_{i}$

$\left(\sum X_{i}\right)^{2}=$ Jumlah item Xi dikuadratkan

$\mathrm{N}=$ Jumlah responden

Nilai korelasi yang diperoleh dikonsultasikan ke tabel Product Moment dengan taraf $A=0,05$ atau a $=0,01$. Jika harga rhitung $>$ rtabel maka reliable dan harga rhitung $<$ rtabel berarti tidak reliabel (Riduwan, 2014).

\section{Minat Belajar Siswa}

Untuk menghitung angket tingkat minat siswa digunkan persamaan berikut:

Tabel 2. Penilaian Skala 1-5 Minat Belajar

Siswa

\begin{tabular}{|l|l|}
\hline \multicolumn{1}{|c|}{ Interval } & \multicolumn{1}{c|}{ Kriteria } \\
\hline$(M+1,50 s)<X$ & Sangat baik \\
\hline$(M+0,50 s)<X \leq(M+1,50 s)$ & Baik \\
\hline$(M-0,50 s)<X \leq(M+0,50 s$ & Cukup baik \\
\hline$(M-1,50 s)<X \leq(M-0,50 s$ & $\begin{array}{l}\text { Kurang } \\
\text { baik }\end{array}$ \\
\hline$X \leq(M-1,50 s)$ & Tidak baik \\
\hline & (Azwar, 2015)
\end{tabular}

Keterangan:

$X=$ Total skor responden

$\mathrm{M}=$ Mean ideal, $1 / 2$ (skor maksimal ideal+skor minimal ideal)

$\mathrm{s}=$ Simpangan baku ideal, 1/6 (skor maksimal ideal-skor minimal ideal)

Data minat belajar siswa diolah tiap pertanyaan kemudian diolah berdasarkan indikator. Data perindikator setelah diolah maka minat belajar siswa dapat diketahui. Data minat belajar siswa dihitung dengan persamaan berikut:

$$
\% N-\text { gain }=\left(\frac{n}{N}\right) x 100 \%
$$

Keterangan:

$$
\begin{aligned}
& n=\text { skor yang diperoleh } \\
& N=\text { jumlah seluruh skor maksimal }
\end{aligned}
$$

(Ali, 2013)

Analisis data gain dilakukan untuk melihat efek dari metode penggunaan media pembelajaran kamus IPA fisika bergambar. Hal ini dapat dilakukan dengan menggunakan persamaan uji gain berikut:

$$
N_{\text {gain }}=\frac{S_{\text {post }}-S_{\text {pre }}}{S_{\text {maks }}-S_{\text {pre }}}
$$

Keterangan:

$$
\begin{aligned}
& N \text {-gain = gain ternormalisasi } \\
& S_{\text {pre }}=\text { skor awal (pree test) } \\
& S_{\text {post }}=\text { skor akhir (post test) }
\end{aligned}
$$


$\mathrm{S}_{\text {maks }}=$ skor maksimal

Hasil perhitungan diinterpretasikan dengan menggunakan gain ternormalisasi sebagai berikut.

Tabel 3. Kriteria Nilai N-Gain

\begin{tabular}{|l|l|}
\hline Nilai gain standar & Keterangan \\
\hline$\geq 0,7$ & Tinggi \\
\hline $0,7 \geq g \geq 0,3$ & Sedang \\
\hline$\leq 0,3$ & Rendah \\
\hline
\end{tabular}

(Hake, 1998)

\section{HASIL DAN PEMBAHASAN \\ Hasil Penelitian \\ Metode Penelitian Tahap I \\ Potensi dan Masalah}

Penelitian dapat berangkat dari potensi dan masalah yang ada. Potensi adalah segala sesuatu yang bila didayagunakan akan memiliki nilai tambah (Sugiyono,2017). Potensi yang ditemukan dalam penelitian ini adalah kamus IPA fisika bergambar dalam kegiatan pembelajaran. Masalah dalam penelitian ini adalah kurangnya minat belajar siswa kelas SMP/MTs kelas VIII terhadap mata pelajaran Fisika. Adanya permasalahan yang mengakibatkan kurangnya minat belajar yaitu metode pengajaran yang digunakan oleh guru kurang efektif, kurangnya menggunakan media pembelajaran sebagai media tambahan untuk menarik minat belajar siswa, dan tidak tersedianya buku pelajaran bagi masingmasing siswa sebagai pegangan untuk belajar dirumah.

Oleh karena tidak tersedianya buku pelajaran bagi masing-masing siswa sehingga setiap pelajaran wajib mencatat untuk mengejar materi. Permasalahan tersebut harus segera diatasi dan diperlukan suatu cara, bukan hanya sekedar strategi dan model pembelajaran yang cocok digunakan oleh guru selama proses pembelajaran, namun yang paling penting adalah media pembelajaran tambahan yang dapat membatu siswa dalam belajar sehingga tidak perlu mencatat semua materi setiap pertemuan. Salah satu media pembelajaran yang tepat dan sesuai untuk meningkatkan minat belajar siswa adalah media pembelajaran kamus IPA fisika bergambar .

\section{Mengumpulkan Informasi}

Pengumpulan informasi dilakukan dengan observasi sehingga diperoleh informasi bahwa siswa kelas VIII di MTs NW Senyiur memiliki minat yang masih kurang. Observasi dilakukan dengan menanyakan permasalahan pada guru yang mengajar dan melakukan pengamatan dalam kegiatan pembelajaran dikelas.

\section{Desain Produk}

Berdasarkan kondisi yang telah ada di sekolah, dapat diketahui bahwa dalam pelaksanaan pembelajaran media buku yang praktis sangat dibutuhkan oleh siswa. Buku pelajaran disekolah yang digunakan guru untuk mengajar masih kurang membantu untuk meningkatkan minat belajar. Buku pelajaran yang digunakan dalam pembelajaran memiliki pembahasan materi yang panjang sehingga siswa cepat merasa bosan dalam membacanya kemudian sulit memahami konsep dalam buku tersebut. Dengan demikian, maka diperlukan buku yang mampu meningkatkan minat belajar pada siswa.

Berdasarkan kondisi yang telah ada disekolah, peneliti mengembangkan kamus IPA fisika bergambar yang terdiri dari cover kamus, materi singkat, dan daftar istilah. Kamus IPA fisika bergambar yang dibuat memiliki jenis dan ukuran tulisan yang mudah dibaca. Desain awal produk dikerjakan dengan menggunakan adobe photosop 7,0, corel draw, microsoft word 2007 kemudian dicetak dengan menggunakan kertas A4.

\section{Hasil Validasi Ahli}

Kegiatan validasi media pembelajaran kamus IPA fisika bergambar dilakukan para ahli dengan mengisi angket yang berisi 28 pertanyaan yang terdiri dari kriteria pendidikan, kriteria tampilan, dan kriteria teknis. Media pembelajaran fisika berbantuan Kamus IPA Fisika bergambar divalidasi oleh 4 ahli yang dianggap respresentasi dan berpengalaman mengajar materi IPA Fisika. Angket diisi oleh ahli yang terdiri 3 orang dosen dan 1 guru MTs NW Senyiur. Hasil validasi media pembelajaran IPA fisika bergambar adalah sebagai berikut :

\section{Ahli I}

Sesuai dengan hasil pengisian angket dari Islahudin, S.Pd, M.Pfis, selaku ahli I, rata-rata nilai yang diberikan pada kriteria pendidikan, tampilan, teknis, isi berada pada skala 4 (setuju). Sementara pengisian angket tertinggi pada kriteria Tampilan dan teknis berada pada skala 4 (setuju) pada skala tampilan pada item soal nomor 3, 5,6,8 dan 9 sedangkan pada kriteria teknis pada item 1, 3, 5, 7 dan 8. Dan pengolahan data dari pengisian angket oleh ahli I untuk kriteria tampilan, untuk kriteria teknis, untuk kriteria pendidikan, untuk kriteria isi berada pada baik dan ahli I merekomendasikan perbaikan pada cover dan gambar harus di perjelas (jangan buram) dan konsep fisika tentang Optik harus sesuai dengan konsep kamus. Dapat disimpulkan penilain dari ahli I bahwa media dapat digunakan namun perlu direvisi. 


\section{Ahli II}

Pengisian angket dari Zulkarnain, M.Si selaku ahli II diperoleh pengisian angket tertinggi berada di skala 4 yaitu setuju pada kriteria pendidikan, tampilan, tekhnik, dan isi pada semua item.. Dari hasil pengisian angket praktisi untuk kualitas pendidikan, kualitas tampilan dan kualitas teknis diperoleh hasil pengolahan datanya menggunakan interval berada pada kriteria sangat baik.

\section{Ahli III}

Pengisian angket dari Isnaini, M.Pd selaku ahli III diperoleh pengisian angket tertinggi berada di kriteria tekhnik dan tampilan pada item nomor 8 , dan 9 , berada pada skala 5 yaitu sangat setuju, sedangkan kriteria tampilan item no 4 , pada skala 5 yaitu sangat setuju dan kriteria pendidikan item no , 2, 3, 4, dan 5, berada pada skala 4 yaitu setuju. Sedangkan pengisian angket terendah pada kriteria isi berada pada skala 2 . Dari pengolahan datanya menggunkan interval diperoleh hasil pengisian angket ahli III untuk kualitas pendidikan baik, kualitas tampilan baik dan kualitas teknis baik. Ahli III merekomendasikan perbaikan revisi pada daftar isi tidak lengkap, fokus pada materi optik dan tidak boleh ada contoh soal.

\section{Praktisi}

Hasil pengisian angket dari Miftahul Jannah, S.Pd selaku praktisi bahwa pengisian angket tertinggi pada skala 5 (sangat setuju) pada item no 8 pada kriteria tampilan, dan item no 5 pada kriteria teknis. Sedangkan pengisian angket terendah berada pada skala 3 (kurang Setuju). Dari hasil pengisian angket praktisi untuk kualitas pendidikan, kualitas tampilan dan kualitas teknis diperoleh hasil pengolahan datanya menggunakan interval berada pada kriteria sangat baik.

Berikut bagian cover kamus IPA fisika bergambar yang akan direvisi adalah:

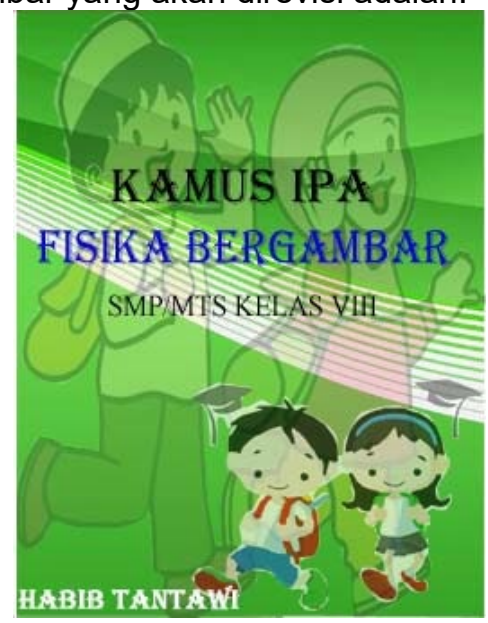

Gambar 2. Sebelum Direvisi

\section{Revisi produk}

Hasil validasi produk yang telah dilakukan menunjukkan bahwa kamus IPA fisika bergambar harus dilakukan revisi pada bagian tertentu meliputi gambar, materi pada konsep fisika dan cover .

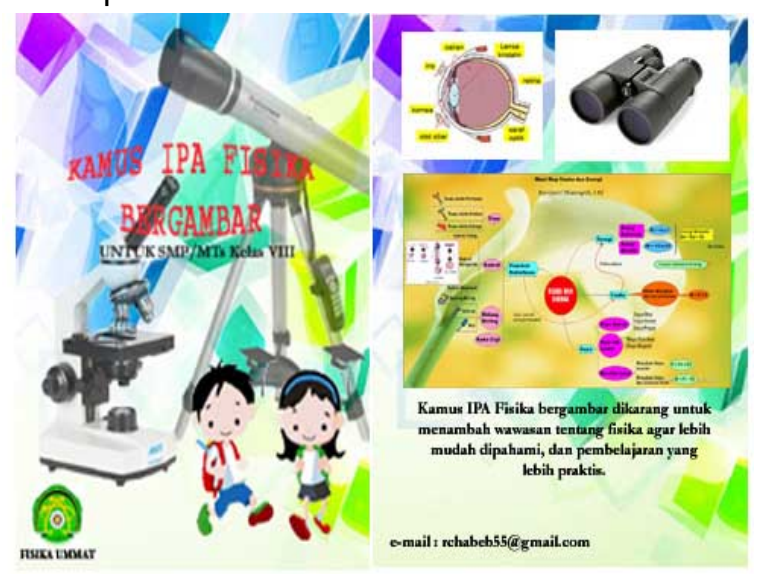

Gambar 3. Sesudah Direvisi pada Bagian Cover.

\section{Metode Penelitian Tahap II \\ Hasil uji validitas angket}

Media pembelajaran selanjutnya diterapkan untuk meningkatkan minat belajar siswa kelas VIII MTs NW Senyiur. Besar minat belajar siswa dapat diukur dengan memberikan angket minat belajar kepada siswa. Ada beberapa bentuk aspek minat belajar yang ingin diketahui dalam penelitian ini antara, minat berupa disiplin, minat berupa tanggung jawab, minat berupa kreatif, minat berupa komunikatif dan minat berupa teliti.

Uji validitas dilakukan pada pernyataan angket dengan menggunakan persamaan korelasi product moment. Hasil uji validitas angket minat belajar adalah sebagai berikut:

Tabel 4. Hasil Perhitungan Validitas Pernyataan Angket

\begin{tabular}{|l|l|l|}
\hline $\begin{array}{l}\text { Jumlah } \\
\text { Pernyataan }\end{array}$ & Valid & $\begin{array}{l}\text { Tidak } \\
\text { Valid }\end{array}$ \\
\hline 30 & 16 & 14 \\
\hline
\end{tabular}

\section{Hasil Uji Reliabelitas Angket}

Pernyataan pada angket diuji keandalannya dengan menggunakan persamaan alpha cronbach. Hasil uji reliabelitas pada pernyataan dapat dilihat pada tabel berikut ini:

Tabel 5. Hasil Perhitungan Reliabelitas

Pernyataan Angket

\begin{tabular}{|l|l|l|}
\hline $\begin{array}{l}\text { Jumlah } \\
\text { Pernyataan }\end{array}$ & Reliabel & $\begin{array}{l}\text { Tidak } \\
\text { Reliabel }\end{array}$ \\
\hline 30 & 16 & 14 \\
\hline
\end{tabular}




\section{Hasil uji coba}

Uji coba yang digunakan yakni di kelas VIII MTs NW Senyiur dengan mengunakan angket minat yang sudah valid kemudian diberikan kepada siswa sebelum pembelajaran dimulai kegiatan pengisian angket dapat dilakukan selama 15 menit pada awal pertemuan sebelum kegiatan pembelajaran dan diakhir pembelajaran.Kegiatan pembelajaran materi optik.

Perhitungan minat belajar siswa dilakukan pada setiap bentuk aspek atau indikator minat. Hasil angket minat kemudian diolah dengan menggunakan langkah-langkah yang dilakukan. Berdasarkan hasil perhitungan dalam penelitian yang dilakukan, maka dapat dilihat peningkatan minat belajar pada siswa.

Persentase hasil perhitungan minat siswa tiap indikator sebelum dan sesudah menggunakan kamus IPA fisika bergambar dapat dilihat pada grafik berikut ini:

Tabel 6. Grafik Persentase Minat Siswa Setiap Indikator Sebelum dan Sesudah.

\begin{tabular}{|l|l|l|l|l|}
\hline No & $\begin{array}{l}\text { Perhatia } \\
\mathrm{n}\end{array}$ & $\begin{array}{l}\text { Senang/tida } \\
\text { k senang }\end{array}$ & $\begin{array}{l}\text { Kesadar } \\
\text { an }\end{array}$ & $\begin{array}{l}\text { Kema } \\
\text { uan }\end{array}$ \\
\hline Sebelum & 38 & 45,9 & 47,6 & 46 \\
\hline Sesudah & 64 & 69,1 & 72,8 & 69,7 \\
\hline Gain & 0,36 & 0,46 & 0,48 & 0,39 \\
\hline
\end{tabular}

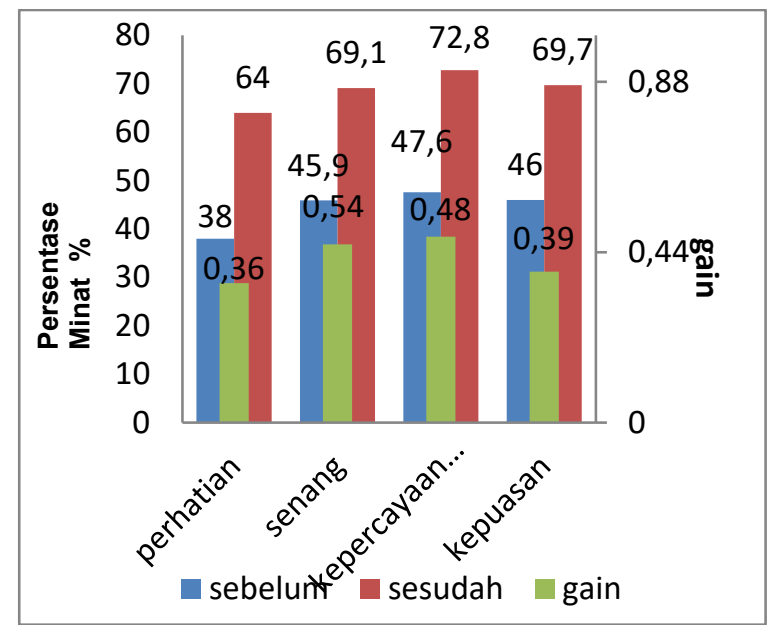

Gambar 4. Persentase Minat Siswa Setiap Indikator Sebelum dan Sesudah Penggunaan Kamus IPA Fisika Bergambar.

Hasil perhitungan minat belajar siswa secara jelas dapat dilihat pada lampiran 13 . Peningkatan minat belajar siswa juga harus dilihat secara klasikal. Dari hasil perhitungan dengan konversi datasecara klasikal, minat belajar siswa mengalami peningkatan. Peningkatan minat secara jelas di buktikan bahwa persentase minat peserta didik menggunakan media konvensional adalah sebanyak $47 \%$. Setelah penggunaan kamus IPA fisika bergambar persentase minat belajar siswa mengalami peningkatan menjadi $70 \%$. Besar peningkatan minat dengan normalisasi nilai gain adalah 0,44 dimana peningkatan minat belajar siswa berada dalam kriteria sedang. Persentase peningkatan minat belajar siswa dapat dilihat pada kedua tabel berikut ini: Tabel 7. Kelompok Minat Siswa Menggunakan Media Konvensional

\begin{tabular}{|c|c|c|}
\hline Interval & $\begin{array}{c}\text { Jumlah } \\
\text { siswa }\end{array}$ & $\begin{array}{c}\text { Tingkat minat } \\
\text { belajar }\end{array}$ \\
\hline$(\mathrm{M}+1,50 \mathrm{~s})<\mathrm{X}$ & - & Sangat baik \\
\hline $\begin{array}{c}(\mathrm{M}+0,50 \mathrm{~s})<\mathrm{X} \leq(\mathrm{M}+ \\
1,50 \mathrm{~s})\end{array}$ & - & Baik \\
\hline $\begin{array}{c}(\mathrm{M}-0,50 \mathrm{~s})<\mathrm{X} \leq(\mathrm{M}+ \\
0,50 \mathrm{~s})\end{array}$ & 8 & Cukup baik \\
\hline $\begin{array}{c}1,50 \mathrm{~s})<\mathrm{X} \leq(\mathrm{M}- \\
0,50 \mathrm{~s})\end{array}$ & 8 & Kurang baik \\
\hline $\mathrm{X} \leq(\mathrm{M}-1,50 \mathrm{~s})$ & 1 & Tidak baik \\
\hline
\end{tabular}

Tabel 8. Kelompok Minat Siswa Menggunakan kamus IPA fisika bergambar

\begin{tabular}{|c|c|c|}
\hline Interval & $\begin{array}{c}\text { Jumlah } \\
\text { siswa }\end{array}$ & $\begin{array}{c}\text { Tinkat Minat } \\
\text { Belajar }\end{array}$ \\
\hline$(\mathrm{M}+1,50 \mathrm{~s})<\mathrm{X}$ & 5 & Sangat baik \\
\hline $\begin{array}{c}(\mathrm{M}+0,50 \mathrm{~s})<\mathrm{X} \leq(\mathrm{M}+ \\
1,50 \mathrm{~s})\end{array}$ & 10 & Baik \\
\hline $\begin{array}{c}(\mathrm{M}-0,50 \mathrm{~s})<\mathrm{X} \leq(\mathrm{M}+ \\
0,50 \mathrm{~s})\end{array}$ & 2 & Cukup baik \\
\hline $\begin{array}{c}0,50 \mathrm{~s}) \\
(\mathrm{M}-1,50 \mathrm{~s})<\mathrm{X} \leq(\mathrm{M}-\end{array}$ & - & Kurang baik \\
\hline $\mathrm{X} \leq(\mathrm{M}-1,50 \mathrm{~s})$ & - & Tidak baik \\
\hline
\end{tabular}

Tabel 9. Grafik Persentase Peningkatan Minat

\begin{tabular}{|c|c|c|}
\hline \multicolumn{3}{|c|}{ Belajar Klasikal } \\
\hline Sebelum & Sesudah & Gain \\
\hline 47 & 70 & 0,44 \\
\hline
\end{tabular}

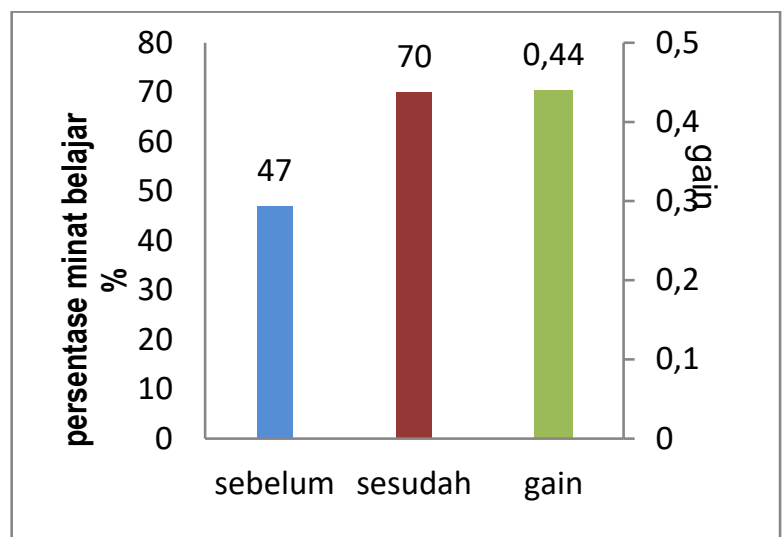

Gambar 5. Persentase Peningkatan Minat Belajar Secara Klasikal

\section{Metode Penelitian Tahap I \\ Potensi dan Masalah}

Berdasarkan hasil observasi peneliti, di MTs NW Senyiur ditemukan permasalahan terkait dengan pembelajaran fisika. Salah satunya adalah para siswa sedikit sekali yang tertarik pada pelajaran fisika. Hal ini disebabkan adanya anggapan bahwa pelajaran fisika banyak sekali rumus-rumus dan sukar 
dipahami. Rendahnya minat belajar siswa ini juga ditunjukan dengan jarangnya siswa mengajukan pertanyaan, malasnya peserta didik mencatat materi pelajaran dan kurangnya respon terhadap pertanyaan yang disampaikan oleh guru. Salah satu penyebabnya adalah kurang buku pegangan siswa untuk belajar di rumah dan siswa harus mencatat dan memfoto copy materi untuk proses belajar mengajar dikelas.Berdasarkan potensi yang ditemukan ini, peneliti bermaksud mengembangkan media berupa kamus IPA fisika bergambar.

\section{Desain Awal Produk \\ Kondisi pada potensi dan masalah yang ada mendorong peneliti untuk} mengembangkan evaluasi berupa kamus IPA fisika bergambar. Kamus IPA fisika bergambar memiliki kelebihan antara lain dapat meminati siswa dalam proses belajar bahkan diluar pembelajaran.

Media pembelajaran kamus IPA fisika bergambar yang dihasilkan yaitu terdiri dari cover kamus IPA fisika bergambar, kata pengantar, daftar isi, materi, kegiatan percobaan dan evaluasi. Kamus IPA fisika bergambar yang dibuat memiliki jenis dan ukuran tulisan yang mudah dibaca serta konsistensi penomoran pada halamannya. Desain awal produk dikerjakan dengan menggunakan program microsoft office word 2007, adobe photoshop 7,0, dan corel draw kemudian dicetak dengan menggunakan kertas A4 untuk mengukur minat belajar siswa.

\section{Hasil Validasi Ahli}

Media pembelajaran yang telah di desain divalidasi oleh ahli sebelum diuji pada kelompok kecil. Validasi kamus IPA fisika bergambar dilakukan oleh 3 ahli 1 praktisi.

Hasil validasi dari ahli praktisi mengatakan tidak ada revisi terhadap produk karena sudah dikatakan layak untuk digunakan. Hasil yang berbeda diperoleh dari ahli I, II dan III merekomendasikan perbaikkan meliputi gambar evaluasi, cover, materi dalam konsep fisika pada kamus IPA fisika bergambar, layak digunakan dalam pembelajaran setelah melakukan revisi.

\section{Revisi Produk}

Revisi produk Kamus IPA Fisika Bergambar dilakukan pada pemberian cover dan gambar pada Kamus IPA Fisika Bergambar edisi kedua, memberikan cakupan materi harus sesuai dengan konsep, dan konsep fisika harus sesuai dengan buku kamus yang dibuat.

\section{Metode Penelitian Tahap II}

Penggunaan media pembelajaran kamus IPA fisika bergambar di MTs NW Senyiur untuk meningkatkan minat belajar siswa pada mata pelajaran Fisika materi optik. Sebelum menerapkan media pembelajaran kamus IPA fisika bergambar, siswa mengisi angket minat belajar yang sebelumnya telah divalidasi. Angket yang telah diisi oleh siswa kemudian diolah untuk mengetahui besar minat siswa.

Minat belajar siswa diolah berdasarkan indikator masing-masing. Jumlah semua indikator adalah 4. Untuk indikator perhatian jumlahnya ada 2 untuk indikator minat belajar yang kedua adalah Senang dengan jumlah masing-masing 4 item, untuk indikator minat belajar yang ketiga adalah kepercayaan diri dengan jumlah masing-masing 6 item sedangkan yang ke empat adalah kepuasan dengan banyak 4 item.

Dalam pengukuran minat belajar siswa digunakan teknik analisis data berupa data kuantitatif, yang diperoleh peningkatan dengan menggunakan normalisasi gain (gain) untuk minat belajar berupa perhatian 0,36 dengan kriteria sedang, minat belajar senang/tidak senang 0,46 dengan kriteria sedang, minat belajar kepercayaan diri 0,48 dengan kriteria sedang, dan minat belajar kepuasan 0,39 dengan kriteria sedang. Jadi peningkatan minat belajar secara klasikal berada pada kriteria sedang normalisasi gain sebesar 0,44.

Berdasarkan penelitian yang telah dilakukan, media pembelajaran berbasis kamus IPA fisika bergambar ini telah teruji keefektifannya dan mempunyai pengaruh terhadap peningkatan minat belajar siswa di MTs NW Senyiur.

\section{SIMPULAN DAN SARAN Simpulan}

Berdasarkan penelitian yang telah dilaksanakan dapat disimpulkan bahwa media pembelajaran berupa Kamus IPA Fisika Bergambar dapat:

1. Teruji kevalidannya baik dari segi ahli media maupun materi, dimana untuk kriteria pendidikan, untuk kriteria tampilan, dan kriteria teknis, 2 ahli memberikan nilai $B$ (baik) dan 2 ahli memberikan nilai $A$ (sangat baik). Jadi untuk keseluruhan kriteria mendapat rata-rata nilai 2 nilai $A$ dan 2 nilai $B$ (baik).

2. Proses pembelajaran berjalan dengan lancar, karena respon siswa yang baik terhadap kamus IPA fisika bergambar yang menjadi sumber belajar.

3. Teruji keefektifannya karena mampu meningkatkan minat belajar siswa kelas 
VIII MTs NW Senyiur pada materi optik. Dimana diperoleh gain untuk minat belajar berupa perhatian 0,36 dengan kriteria sedang, minat belajar berupa senang 0,46 dengan kriteria sedang, minat belajar berupa kepercayaan diri 0,48 dengan kriteria sedang dan yang terakhir minat belajar berupa kepuasan 0,39 dengan kriteria sedang. Sedangkan Peningkatan minat belajar secara klasikal juga berada pada kriteria sedang dengan normalisasi gain sebesar 0,44.

\section{Saran}

Berdasarkan penelitiaan yang telah dilakukan, maka diberikan beberapa saran bagi peneliti selanjutnya yaitu:

1. Kamus IPA fisika bergambar yang dikembangkan dapat digunakan dengan baik, namun masih memiliki kekurangan baik dari segi pendidikan, tampilan, dan kualitas teknis. Hal ini dapat dijadikan pertimbangan bagi peneliti selanjutnya untuk mengembangkan media pembelajaran yang lebih sempurna lagi.

2. Kamus IPA fisika bergambar ini dapat dikembangkan untuk semua materi Fisika untuk materi yang berbeda.

Penelitian ini dilaksanakan sampai pada tahap uji coba kelompok kecil.Oleh karena itu diharapkan pada penelitian selanjutnya dilaksanakan sampai pada tahap penyebaran.

\section{DAFTAR RUJUKAN}

Amdestiana EAB (2017). Repository.ump.ac.id. diakses pada taggal 12 desember 2016.

Budiarti, Rini, dkk. (2015). Kajian Kualitatif Efektivitas Blended Learning Ipa Terpadu Berbasis Sets Di Smp Wilayah Eks Karesidenan Surakarta. JPMF, Vol, 5, No 1, 2015 ISSN : 2089-615.

Erma F. ( 2012), Media Pembelajaran, https://eprints.uny.ac.id/9432/12/12 \%20BAB\%20II-08503247004.pdf.

Diakses pada tanggal 12 desember 2018.

Islahudin., Darmayanti, N. W. S., Zulkarnain, (2017), Pengaruh Pemanfaatan Alat Peraga Berbasis Kearifan Lokal Terhadap Peningkatan Hasil Belajar Fisika Pada Siswa Kelas VIII di MTS Nurul Iman NW Kembang Kerang Lombok Tengah Tahun Pelajaran 2017/2018, ORBITA:Jurnal Kajian, Inovasi dan Aplikasi Pendidikan Fisika, 3(2), 46-52
Isnaini, M., Sabaryati, J., \& Fadillah, Alfiah, (2019). Pengembangan LKS G-JKO Pada Mata Pelajaran IPA Fisika Siswa MTs Al-Raisiyah Mataram. ORBITA:Jurnal Kajian, Inovasi dan Aplikasi Pendidikan Fisika, 5(1), 1522.

Mikraj, Abdul., Utami, L. Sekar., Zulkarnain, (2019), Pengaruh Buletin Fisika Berbentuk Buku Saku Untuk Meningkatkan Hasil Belajar Siswa di MAN 2 Bima Kelas X Materi Hukum Newton Tahun Pelajaran 2018/2019, ORBITA:Jurnal Kajian, Inovasi dan Aplikasi Pendidikan Fisika, 5(1), 5-14

M. Laeli (2012), Media Pembelajaran, https://eprints.uny.ac.id/8323/3/BAB \%202\%20-\%2008513241018.pdf. Diakses pada tanggal 12 desember 2018.

Murviza, R.O.,Lizelwati. N., dan Trisoni, R. (2014). Pengembangan Kamus Fisika Bergambar untuk Materi Fisika MTsS Plus Balimbing Kelas VIII. Edusainstika, 1(1):28-29

Nurlaelah, N., Sabaryati, J., \& Zulkarnain, Z, (2019). Pengembangan Media Pembelajaran Kotak Pop Up Untuk Meningkatkan Motivasi Belajar Siswa Materi Cahaya Dan Alat Optik Kelas VIII SMPN 19 Mataram. ORBITA:Jurnal Kajian, Inovasi dan Aplikasi Pendidikan Fisika, 5(1), 1522

Sari Yunita, dan Mutari Mukarramah (2017). Pengembangan Media Gambar Berupa Buku Saku Fisika SMP Pokok Bahasan Suhu dan Kalor. Jurnal IImiah Al-BiRuNi, Vol.6, No 1, April 2017-ISSN 2303-1832.IAIN Intan Lampung

Soenarto (2008). Metode Penelitian R\&D. Institut Bisnis dan Informatika. Sir.Stikom.edu/2070/6/BAB_IV.pdf.

Sugiyono. (2010). Metode Penelitian Kuantitatif Kualitatif dan $R$ \& $D$. Bandung: Alfabeta.

Utami, L.S., Darmayanti, N.W.S, (2019). Efektifitas Pembelajaran Multirepresentasi Untuk Meningkatkan Pemahaman Konsep Mahasiswa Fisika Materi Gelombang Dan Optik Tahun Akademik 2018/2019, ORBITA:Jurnal Kajian, Inovasi dan Aplikasi Pendidikan Fisika, 5(1), 5358 